\title{
Verse Epitaphs and the Memorialisation of Women in Reformation England
}

\section{Abstract:}

During the late twentieth century, scholars became interested in the ways in which early modern England adapted to the Reformation and how change was represented in popular culture. In the last fifteen years, there has been a particular focus on how Protestantism affected the relationship between the living and the dead. In 2000, for example, Ralph Houlbrooke's study Death, Religion, and the Family in England, 1480-1750 identified a failure on the part of the post-Reformation church to replace old funerary customs with new, yet two years later in Beliefs and the Dead in Reformation England, Peter Marshall argued persuasively that the Reformation engendered a 'cultural transformation' in the understanding of both death and the dead. By 2009, Scott Newstok's Quoting Death in Early Modern England described a paradox in which a Protestant nation that scorned Catholic death rituals became engrossed in commemorating its own dead through poetic memorialisation.

This article surveys 21st century historiographical debates in order to contextualise women's verse epitaphs during the sixteenth century. In particular, it looks to the broadside literature that was the epitome of cheap print as a means of reflecting popular religious attitudes. It shows how several verse epitaphs of prominent women in Tudor society, such as William Elderton's A proper new balad in praise of my ladie marques (1569), highlight issues of continuity and change in religious beliefs surrounding the memorialisation of pious women and the role of the supernatural.

When Margaret Stanley, Countess of Derby, died at Latham in Lancashire in 1559, the family's minstrel, Richard Sheale, composed an epitaph which lamented how, 'Latham allway bothe nyghte and day may morn and mak gret mon, / For the losse of this lady dear, whosse vertus wear well knowene'. ${ }^{1}$ Tradition dictated that when a patron died, his minstrel or gestour would compose an elegy to be performed in the patron's household among his kith and kin. Sheale appears to have led a dual life on the cusp of the medieval and modern worlds, both as minstrel to the Stanley household and as an itinerant and commercial ballad seller (Taylor 1-11). The sixteenth century saw a growing trade in printed eulogies and the publication of a broadside verse epitaph was a logical cultural extension to a minstrel's private elegy, widening the audience for the memorialisation of a wealthy or influential person beyond their immediate household. Tessa Watt commented that, as the importance of printed texts grew, 'it was no longer enough for a death to be marked by an oral tribute from the household's minstrel: now there was apparently a desire to have this eulogy legitimized in print, and distributed in broadside form' (20). Nevertheless, Peter Marshall noted that the growth of printed epitaphs was, in part, a response to the upheavals of the Reformation, as Protestants sought new and acceptable ways to commemorate their dead (275). This article

\footnotetext{
${ }^{1}$ Oxford, Bodleian Library, MS Ashmole 48, f. 109r.
} 
will address the memorialisation of women in verse epitaphs during the sixteenth century, when beliefs about the place of the dead and appropriate commemorative behaviour underwent huge changes.

Between July 1557 and July 1571, 28 epitaphs were registered with the Stationers' Company. ${ }^{2}$ At least 27 sixteenth-century verse eulogies survive in print, and 20 of these can be assumed to have been aimed at a mass market, presented as they were in black-letter on broadsides, the favoured typeface of the typical Tudor ballad. Although they are too long to have appeared on tombs, the fact remains that many of these printed verses are entitled 'epitaph' and, as Scott Newstok's landmark study Quoting Death in Early Modern England showed, the epitaph was a constraint-defying genre (13-15). This article therefore treats both the epitaph and the ballad as broad and overlapping categories.

Ballads were an ephemeral form of popular, narrative verse (Simpson 1). The term hints at an intention to perform, although many did not indicate a tune and only a small number of broadsides included musical notation. Natascha Würzbach noted that ballads used simple language, rhyme and straightforward metre (1), while Tessa Watt argued that the genre contained many different types of song and that distinctions constantly broke down 'as a natural result of the process of oral dissemination' (13). Epitaphs, of course, imply a physical monument, an engraving upon a tomb, but printed broadsides are a poetic genre which often gesture towards a tomb only through their words. When the epitaph appeared in cheap print that the boundaries between them and ballads were dramatically blurred. They share stylistic features of rhythm and rhyme, material features of paper and print, and the same need to memorialise the dead.

How these poetic epitaphs were used remains a vexed question. The epitaphs' regular metre and rhyme makes it possible that they were recited, while we can be confident that those by Sheale and the prominent balladeer William Elderton were intended to be sung. Ralph Houlbrooke described poetic epitaphs being fixed to hearses and distributed at funerals as well as being sold. He noted that the purpose of an epitaph was 'to show love to the deceased, preserve their memory, comfort their friends, and put the reader in mind of human frailty', but exactly how to commemorate deceased family and friends was a matter of contention following the establishment of the Protestant church $(328,351-2)$. The changing and sometimes confused nature of the religious beliefs displayed in these verse epitaphs show that literary scholars need to be keenly aware of the historical background of the works that they study.

Ideals of female virtue

Marshall suggested that changes in mortuary culture redefined social divisions in the memorialisation of the dead, because epitaphs were written only for the socially important (285). The memento mori ballad A dolfull daunce and song of death Intituled the shakeing of the sheetes reminded people that death came to everyone, respecting neither youth nor wealth:

Bringe away the Beggar and the king, and everie man in his degree,

\footnotetext{
${ }^{2}$ The registers of the Company of Stationers begin in July 1557, but there is a gap in the records from July 1571, after which only cash accounts exist for much of the rest of the sixteenth century. The period 1557-1571 is therefore the most appropriate for a study of sixteenth-century book entries. See Arber.
} 
bring away both ould and youngest thinge

come all to death, and follow me. ${ }^{3}$

As Scodel noted, however, 'All men must die, but the social order based on distinctions of rank endured. Monuments kept death the leveller at bay with visible "proof" that social distinctions prevailed over death' (17). Likewise, poetic epitaphs were printed only for the elite. Fewer survive for women than men, and none for women of the lower sorts. Despite Patricia Phillippy's contention that commemorative works for women emerged in the last decades of the sixteenth century (84), it appears that the memorialisation of women, in cheap print at least, had in fact developed over a much longer period. The earliest extant printed epitaph for a woman was an Epitaph vpon the Death of the Excellent and our late vertuous Quene, Marie, deceased, augmented by the first Author. Presumably this was the Epithaphi of quene MARY which Richard Lant printed without license in 1558 (Arber 1: 101).

A ballad epitaph exploited people's curiosity about the lives and deaths of outstanding members of society in order to create and reinforce ideals of man or womanhood, a 'good' Christian death or the significance of good works. Newstok noted that the most frequent criticism levelled at epitaph-writers was that of excessive praise verging on the hypocritical, particularly when it came from authors who had not known the subject personally (145). Certainly, the verse epitaphs of these model women might seem overly flattering. The women were presented as perfect Christians. These commonplaces, however, provided archetypes of female conduct that women, be they Protestant or Catholic, were expected to emulate. Margaret Stanley’s 'vertus wear well knowen':

she never hurte man woman nor childe I dar well say and prove she never hurte non off her men in worde nor yete in dede but was glade allway for them to speake such tym as the had ned. ${ }^{4}$

Mary I was the 'lampe of vertue's light', 'Constante, courtise, modest, and mylde, a chast and chosen wife'. During her 'perfecte life', 'all worldly pompe she set at nought, to praye was her delight' (vertuous Quene). The Protestant Lady Avenon's epitaph claimed that her 'flowynge vertues were not hyd whyle she enioyed lyfe' and that, with her death, the poor 'lost a nurse to helpe their nedie state' (Philips, vertuous matrone). But although both Protestants and Catholics emphasised the exemplary qualities of their subjects, the implications of those qualities were rather different.

Sheale's ballad epitaph for the countess of Derby, for example, records the death of a devout Catholic gentrywoman, but the accession of the Protestant Elizabeth I on 17 November 1558 had sounded the death-knell for Catholicism in the English church. Although Tessa Watt (20) and Andrew Taylor (22-24) make much of the fact that the title given to the Stanley epitaph was reminiscent of those to be found on broadside epitaphs, it seems unlikely that these explicitly Catholic verses would have been printed legally under the Protestant Elizabeth I. As Alison Shell pointed out, during this period, it was safer to circulate Catholic material in manuscript or even through oral transmission (16-7). The verses seem not to have appeared in print, unlike many of the other ballads from the same manuscript collection.

Sheale's verses also reflect a far more personal approach to the subject than many printed epitaphs. While ballads and epitaphs both use emotional language to draw in the audience

\footnotetext{
${ }^{3}$ London, British Library, Add. MS 15225, ff. 15r-16r.

${ }^{4}$ MS Ashmole 48, f. 109r.
} 
(Marsh 242; Würzbach 41-3), Sheale's use of reported speech is detailed, inclusive and familiar, making the audience feel involved in the events which took place at the countess's deathbed. The countess's final words were reported to the audience as an example of a 'godly ende':

lord gode quothe she I com[m]en my sprite in to thy holy handes for thowe frome syne haste sete me fre, and broken all my bandes be cristis dethe and passione she sayd I trust savyd to be

then yeldyde she up the goste and gave her selffe to dye. ${ }^{5}$

Shortly before she died, the countess requested the viaticum, taking the holy bread and wine for the final time. Sheale goes on to describe the Mass sung by Thomas Stanley, bishop of Sodor and Man, for the countess's funeral, even detailing the black attire of the mourners and the 'godly dede' of 'twese after forty pound' set aside for donations to the poor of eight parishes around Ormskirk in Lancashire. For Catholics, charitable acts in life and death were carried out for the benefit of the soul. Houlbrooke noted that bequests for funeral doles were widespread among the gentry prior to the Reformation, in order to encourage the poor to pray for the soul of the deceased (114). By the Protestant Elizabethan age such bequests were seen as a continuation of women's godly work and confirmed 'the testator's place in the social hierarchy' (Helt 201). Nevertheless, there is little doubt that Catholics like Margaret Stanley continued to believe that if they bequeathed food or money to the poor, in return they would receive intercessory prayers which would speed their soul's journey through Purgatory to heaven. Furthermore, Sheale's ballad closed with a request that his listeners would pray for the countess's soul.

Protestant attitudes to remembering the dead were more contradictory. Many of the traditional rituals surrounding memorialisation, such as the year's mind and intercessory prayers for the dead, were considered not just unnecessary but superstitious. Robert Whiting concluded that, by 1570 , 'The traditional apparatus of intercession had been progressively dismantled, and was now beyond repair'. It had been replaced only by 'uncertainty, confusion, and indifference to the officially sanctioned forms of religion' (139). The Protestant church had dismantled much of the Catholic framework for funerary rites, but it had yet to provide a broadly acceptable alternative. People still felt a need to remember the dead. One solution was to 'set out a pattern of imitable virtue' (Houlbrooke 352). According to Nigel Llewellyn, 'Protestant churches gradually developed the theory of memoria, which stressed the didactic potential of the lives and deaths of the virtuous' (28). Funeral sermons, monuments and ballad eulogies served the same function as pre-Reformation saints' lives. They encouraged their audience to emulate the virtuous example set by the deceased. In doing so, they provided a means to remember the dead within a Protestant framework. Houlbrooke described how virtue and piety were 'the surest basis of lasting fame. They give the deceased a sort of immortality, and make them worthy of imitation, a source of edification for succeeding generations' (353). Peter Marshall concluded that by 'making known the virtues of the godly, preachers were in fact praising God for them, while providing exemplary patterns of piety for the living' (268). Furthermore, Phillippy demonstrated that women could gain posthumous influence through the memorialisation of their pious lives and good deaths, which granted them 'surprising degrees of spiritual and cultural power, associated with the authority of the deathbed itself' (83).

\footnotetext{
${ }^{5}$ MS Ashmole 48, f.108v.
} 
The best-known example of this genre is not a ballad, but a pamphlet. Phillip Stubbes's $A$ christal glasse for christian vvomen contained a

rare and wonderfull example of the vertuous life, and Christian death of Mistresse Katherine Stubbes, who whilest shee liued, was a Myrrour of womanhood, and now being dead, is a perfect patterne of true Christianitie (A2r).

It was a didactic work, intended to 'giue vs grace to folow her good example, that we may come to those vnspeakable ioyes wherin she now resteth'(C3v). A christal glase for christian women was reprinted many times in the century following its first publication in 1591, which suggests that its civilising themes had an on-going appeal long after the death of its subject. Commemorative songs like William Elderton's A proper new balad in praise of my Ladie Marques, Whose death is be wailed, To the tune of new lusty gallant fit into this evolving tradition of mortuary culture. ${ }^{6}$ It was printed four years after the death of its subject, the marchioness of Northampton, Elizabeth Parr (Hyde 542). This may indicate that its themes of courtly love and feminine piety were, like A christal glasse, expected to appeal to a wider audience than just those women who knew her personally. Beth Quitslund concluded that songs 'are especially effective forms of persuasion because they are entertaining' (141). By setting these themes to a lively tune, the ballad gave Parr's memory an afterlife beyond a handful of ladies of the court.

Although he uses commonplaces of virtuous behaviour, Elderton's ballad draws attention to one particularly novel area of Protestant theology: the personal relationship with God created by prayer. In contrast to Sheale's request that others pray for Margaret Stanley so that God might have mercy on her soul, Elderton reflects the Parrs' Protestant faith by suggesting that Elizabeth spent much of her time 'Homblie kneeling one her knee, / As her desire was still to praie'. Protestantism placed its emphasis on solafidianism - the belief that it was the individual believer's faith alone that ensured salvation - rather than relying on good works and intercession. Nancy Lee Beaty suggested that

The doctrines of election, of salvation by faith alone, of the priesthood of all believers, of the perseverance of the saints - these, together with the rejection of purgatory, are indeed 'comfortable' teachings to anyone certain of his own faithfulness (155).

As a member of a leading Protestant family, Elizabeth Parr might be expected to have embraced this belief wholeheartedly. According to Whiting, however, many people saw only a 'new and alien doctrine of justification by faith alone' (139).

\section{Ghost beliefs}

Elderton's choice of imagery, though, is also indicative of the confused nature of belief in the years immediately following the reformation. Patricia Fumerton and Anita Guerrini argued that modern scholars can 'gain access to complex relationships in the early modern period, between popular and learned culture' through popular print such as broadside ballads (8). Elderton's ballad exemplifies the problems faced by mid-sixteenth century writers in reconciling the new Protestant theology with a very human need to remember the dead. $A$ proper new balad exemplifies the ways in which epitaph writers 'exploited conventions that presupposed discarded beliefs and practices in order to imagine relationships between the living and the dead that differed from the conceptions of their contemporaries' (Scodel 6). Elderton imagines that he sees Parr returning as an apparition to carry out further good works

\footnotetext{
${ }^{6}$ The author's transcript and recording of the ballad are available alongside this article on the Literature Compass website.
} 
for those more unfortunate than herself: 'I see her walke in blacke, / In euery corner where I goe'. The ghost is probably symbolic of Elderton's grief rather than a description of a supernatural experience, but it nevertheless reflects how the Reformation changed people's beliefs about death and the afterlife. In describing an imagined ghost, Elderton, perhaps unwittingly, reflects several complications brought about by a period of religious upheavals. The Protestant rejection of purgatory undermined the theological position of the ghost. As far as reforming polemicists were concerned, spirits could not return from purgatory to haunt the living, because there was no purgatory from which to return. In his book A christall glasse of christian reformation wherein the godly maye beholde the coloured abuses vsed in this our present tyme, the Protestant clergyman Stephen Batman searched the bible for evidence of 'this third place, which they cal purgatory, but nought there is to be founde' (Uiir). As Marshall pointed out, Protestants believed that 'Stories about the appearance of ghosts encapsulated the ignorance, credulity, and corruption of papists, whereas the rejection of them by Protestants was symptomatic of a sober scriptural faith' (235). Batman described how

...the Pope and his fraternity, beholde the scriptures but nothing at all vse them as they ought to do, but altogether to their owne imaginations, in as much as they haue done and do mayntayne a purgatory, a place to punishe soules in, after they be departed this life at their pleasures, which is nothing but mere falshod and deceit, ye and also are not ashamed to say that by vertue of trentall Masses, pardo[n]s, and dirgies, they are able to redeme those that are passed this life from all paynes and tormentes (Uiiv).

So it was that John Phillips could be confident that upon her death, Lady Avenon went 'from hence vnto the heauens her christall soule so sweete, / Which now inclosed is with aungelles rownde aboute'. Meanwhile, 'Her corps shall shrowde in claye, the earth her right doth craue'. Her physical body rotted in the earth while her soul reposed in heaven. Nevertheless, as Whiting commented, 'Belief in Purgatory... did not vanish overnight' (135). Ghosts were used in literature throughout the early modern period to show that the dead continued to care for their loved ones from beyond the grave, or to prick the conscience of the living in order to make them lead a better life (Marshall 258).

For Protestant reformers it was impossible for ghosts to be spirits who had returned from purgatory. The precise nature of what such visions might actually be was still the subject of rhetorical debate. The sixteenth-century Swiss theologian Ludwig Lavater acknowledged that 'many naturall things are taken to be ghosts' (49). Sometimes the sick or depressed had visions which they thought to be spirits, while others had profited from feigning the existence of ghosts and angels. He recognised, though, 'that straunge sightes, and many other suche lyke things, are sometymes hearde and also séene' (10). He went on to explain ghostly visions such as those described by the church fathers as 'either a good or euill Angell, or some other forewarning sent by God' (160). By devoting their attention to explaining apparently supernatural events, theologians acknowledged that people still believed in ghosts and that they needed to provide a new explanation for these phenomena. Christopher Marsh described how 'Popular culture absorbed the new without necessarily abandoning the old, and without necessarily resolving the resultant contradictions' (145). Rather than rejecting Catholic doctrine completely, Bruce Gordon described how, when it came to ghosts, many Protestants conjoined 'traditional beliefs with their refined theological positions in a marriage which was not without its contradictions' (106). Belief in the existence of apparitions remained a reality, however unorthodox it may have been.

Elderton's use of an imagined apparition to illustrate the marchioness's qualities supports the view that popular culture was not so easily changed. As Katherine Park and Lorraine Daston 
commented, 'Although broadsides cannot be taken as direct sources for popular culture, they bring us closer than any other texts to the popular audience of the Reformation period' (28). Elderton seems to accept that the apparition of the lady marquess must be a product of his imagination. To do otherwise would have been extraordinary when writing about a prominent Protestant. An apparition with 'face so sweete' and 'cheere so good' could hardly be suffering the painful torments of purgatory to atone for her sins. Although Elderton's 'reason saith, now she is dead', his continued grief causes him to 'make memory for her soule / With weepinge eyes once euerye daye' and creates a vision of the marchioness in his mind's eye. Although Elderton avoids calling the vision a ghost, he uses a familiar trope to play on the idea of a ghost meddling in the affairs of the living.

Locating the body and soul

Newstok agreed with Marshall and Houlbrooke that 'the sudden proliferation of epitaphs in the latter part of the 1500s' was a result of the 'almost total demolition of the primary institutions that had been dedicated to perpetuating the dead' during the Reformation (16).Nevertheless, he related this to the destruction of monuments rather than the shift away from belief in purgatory and its associated intercessory prayers (17-18). During the midsixteenth century, a desire to remove superstitious Catholic verses and idolatrous images resulted in the destruction not only of tombs and gravestones but of religious houses themselves. Newstok claimed that, having devastated Catholic memorials, Protestant England became preoccupied textual memorials instead of relying on rituals such as the funerary Mass and the year's mind (26). 'In the context of destroyed material epitaphs, which had been presumed to endure in perpetuity', Newstok suggested, 'the everyday references to epitaphs, including those for still living figures, conveyed a marked anxiety about memorialization' (18-9). He argued that the epitaph fulfils a human need 'to locate the body, to put it to rest beneath a text. The text itself... goes beyond merely covering the corpse...; it recovers the corpse as having been a human body' (190).

The sixteenth-century women's epitaphs place the deceased body carefully under the text. John Philips' two epitaphs for Margaret Douglas, Countess of Lennox, give detailed descriptions of the location of the corpse, which 'lieth enterred the. 3. day of April at Westminster in the chaple of King Henry the seuenth, her worthie grandfather of Englande, Fraunce and Ireland King'. More modestly, Dame Helen Branch 'humbly gaue her soule to Christ, and left hir corps to clay' (Phillips, Dame Helen Branch). Elderton describes the burial of Elizabeth Parr 'vnder the roufe of sweete Saint Paull, / There lyeth my Ladie buryed in Claye', but his emphasis that the marchioness is 'dead and gone' nonetheless demonstrates his repudiation of purgatory. Parr's exemplary conduct meant that her soul would have gone straight to heaven. Thomas Newton is certain, for example, that Lady Knollys '... hath / the blessed companie / Of Sainctes, Archangels, Patriarches, / and Angelles in degree' because 'in this world /she led a life so right, / That ill report could not distaine, /nor blemish her with spight'. So although the epitaphs were keen to locate the body in the ground, the Protestant verses reflect a confidence that the soul of the righteous was already in heaven.

\section{Conclusion}

Understanding the changing place of the dead is crucial to understanding the sixteenthcentury verse epitaph. The Reformation 'represented in practice a complex and protracted process of cultural exchange, in which the teachings of the reformers were adapted and internalized in sometimes unforeseen ways' (Marshall 311). These adaptations can be seen in sixteenth-century verse epitaphs. Catholic and Protestant women alike were praised as 'mirrors of womanhood', but the reasons why a woman's acts were considered to be virtuous 
changed as a result of the Reformation. While the Catholic Countess of Derby was praised in 1559 for almsgiving that would speed her journey through purgatory, by 1594 John Phillips commended Dame Helen Branch for donating money to the poor and needy as an act of charity which demonstrated nothing more nor less than her godliness. Elderton's ballad, however, shows that although Protestant doctrine relating to the dead was widely known, it had not completely displaced familiar Catholic beliefs. A proper new balad was surely intended as an entertaining piece of poetic ephemera rather than a treatise on theological developments, yet, because it eulogises a member of a prominent Protestant family, it also has something to tell us about the changes in popular culture prompted by the Reformation. The particular historical circumstances in which the mid-sixteenth century broadsides were published affect the way in which they should be read, since they reflect changing perceptions of the genre itself and the beliefs they represented. Above all, they should be approached with sensitivity to the inconsistent progress of the Reformation.

\section{Works Cited}

Arber, Edward, ed. A Transcript of the Registers of the Company of Stationers of London, 1554-1640 A.D., vol. 1. London: Privately printed, 1875.

Batman, Stephen. A christall glasse of christian reformation wherein the godly maye beholde the coloured abuses vsed in this our present tyme... London: John Day, 1569.

Beaty, Nancy Lee. The Craft of Dying: a Study in the Literary Tradition of the 'Ars moriendi' in England. London: Yale University Press, 1970.

Elderton, William. A proper new balad in praise of my Ladie Marques, Whose death is be wailed, To the tune of new lusty gallant. London, 1569. STC (2nd ed.) / 7562.

Epitaph vpon the Death of the Excellent and our late vertuous Quene, Marie, deceased, augmented by the first Author. London: Richard Lant [1558].

Fumerton, Patricia, and Anita Guerrini. 'Introduction: Straws in the Wind.' Ballads and Broadsides in Britain, 1500-1800. Ed. Patricia Fumerton, Anita Guerrini and Kris McAbee. Farnham: Ashgate, 2010. 1-9.

Gordon, Bruce. 'Malevolent Ghosts and Ministering Angels: Apparitions and Pastoral Care in the Swiss Reformation.' The Place of the Dead in Late Medieval and Early Modern Europe. Ed. Bruce Gordon and Peter Marshall. Cambridge: Cambridge UP, 2000. 87-109. Helt, J.S.W. 'Women, Memory and Will-making in Elizabethan England.' The Place of the Dead: Death and Remembrance in Late Medieval and Early Modern Europe. Ed. Bruce Gordon and Peter Marshall. Cambridge: Cambridge UP, 2000. 188-205.

Houlbrooke, Ralph A. Death, Religion, and the Family in England, 1480-1750. Oxford: Oxford UP, 2000.

Hyde, Jenni. 'William Elderton's Ladie Marques Identified.' Notes and Queries 260:4 (2015): 541-2.

Newton, Thomas. An epitaphe vpon the worthy and honorable lady, the Lady Knowles. London: William How, for Richarde Iohnes, 1569. STC (2nd ed.) / 18512.

Lavater, Ludwig. Of ghostes and spirites walking by nyght... And translated into Englyshe by R.H. London: Henry Benneyman for Richard VVatkyns, 1572. STC (2nd ed.) / 15320. Llewellyn, Nigel. The Art of Death: Visual Culture in the English Death Ritual c.1500c.1800. London: Reaktion in association with the Victoria and Albert Museum, 1991. Marsh, Christopher W. Popular Religion in Sixteenth-Century England: Holding Their Peace. Basingstoke: Macmillan, 1998.

---. Music and Society in Early Modern Enlgand. Cambridge: Cambridge UP, 2010. Marshall, Peter. Beliefs and the Dead in Reformation England. Oxford: Oxford UP, 2002. 
Newstok, Scott L. Quoting Death in Early Modern England: The Poetics of Epitaphs Beyond the Tomb. Basingstoke: Palgrave Macmillan, 2009.

Park, Katherine and Lorraine F. Daston. 'Unnatural Conceptions: The Study of Monsters in Sixteenth- and Seventeenth-Century France and England.' Past \& Present 92 (1981): 20-54. Phillippy, Patricia Berrahou. Women, Death and Literature in Post-Reformation England. Cambridge: Cambridge UP, 2002.

Phillips, John. An epitaph on the death of the vertuous matrone, the Lady Maioresse... London: Richard Iohnes, 1570. STC (2nd ed.) / 19868

---. A commemoration of the right noble and vertuous ladye, Margrit Duglasis good grace... London: John Charlewood, 1578. STC (2nd ed.) / 19864.

---. An epitaphe on the death of the right noble and most vertuous lady Margarit Duglasis... London: Edward White, 1578. STC (2nd ed.) / 19866.

---. A Commemoration of the life and death of the Right Worshipfull and vertuous Ladie, Dame Helen Branch... London, 1594. STC (2nd ed.) / 19863.7.

Quitslund, Beth. The Reformation in Rhyme: Sternhold, Hopkins and the English Metrical Psalter, 1547-1603. Aldershot: Ashgate, 2008.

Shell, Alison. Oral Culture and Catholicism in Early Modern England. Cambridge: Cambridge UP, 2008.

Simpson, Claude. The British Broadside Ballad and its Music. New Brunswick: Rutgers UP, 1996.

Stubbes, Phillip. A christal glasse for christian vvomen ... London: Richard Ihones, 1591. STC (2nd ed.) / 23381.

Taylor, Andrew. The Songs and Travels of a Tudor Minstrel: Richard Sheale of Tamworth. York: York Medieval Press, 2012.

Watt, Tessa. Cheap Print and Popular Piety, 1550-1640. Cambridge: Cambridge UP, 1991. Whiting, Robert. "For the Health of My Soul": Prayers for the Dead in the Tudor SouthWest.' The Impact of the English Reformation, 1500-1640. Ed. Peter Marshall. London: Arnold, 1997. 121-42.

Würzbach, Natascha. The Rise of the English Street Ballad, 1550-1650. Trans. Gayna Wells. Cambridge: Cambridge UP, 1990.

\section{Further Reading}

Aston, Margaret. 'Death.' Fifteenth-Century Attitudes: Perceptions of Society in Late Medieval England. Ed. R. Horrox. Cambridge: Cambridge UP, 1994. 202-228.

Becker, L.M. Death and the Early Modern Englishwoman. Aldershot: Ashgate, 2003. Bennett, G. 'Ghost and Witch in the Sixteenth and Seventeenth Centuries.' Folklore 97 (1986): 3-14.

Cressy, David. Birth, Marriage and Death: Ritual, Religion and the life-cycle in Tudor and Stuart England. Oxford: Oxford UP, 1997.

Daniell, Christopher. Death and Burial in Medieval England, 1066-1550. London:

Routledge, 1997.

Davies, O. The Haunted: A Social History of Ghosts. Basingstoke: Palgrave Macmillan, 2007.

Davis, N.Z. 'Ghosts, Kin, and Progeny: Some Features of Family Life in Early Modern France.' Daedalus 106 (1977): 87-114.

Doebler, B.A. Rooted Sorrow: Dying in Early Modern England. London: Associated University Presses, 1994. 
Duffy, Eamon. The Stripping of the Altars: Traditional Religion in England c.1400-c.1580. London: Yale UP, 1992.

Dymond, D. 'God's Disputed Acre.' Journal of Ecclesiastical History 50 (1999): 464-97. Gordon, Andrew, and Thomas Rist, eds. The Arts of Remembrance in Early Modern England: Memorial Cultures of the Post Reformation. Farnham: Ashgate, 2013.

Greenblatt, S. Hamlet in Purgatory. Princeton: Princeton UP, 2001.

Harding, V. The Dead and the Living in Paris and London, 1500-1670. Cambridge:

Cambridge UP, 2002.

Harris, B. J. 'The Fabric of Piety: Aristocratic Women and Care of the Dead, 1450-1550.' Journal of British Studies 48:2 (2009): 308-355.

Houlbrooke, Ralph. The English Family 1450-1700. London: Longman, 1984.

Hutton, Ronald. 'The English Reformation and the Evidence of Folklore.' Past and Present 148 (1995): 89-116.

Jones, Gareth. 'Tomb Monuments as a Form of Self-expression for Aristocratic Women in Early Modern England.' Thesis. Leiden University, 2015.

$<$ https://openaccess.leidenuniv.nl/handle/1887/32008>.

Kay, Dennis. Melodious Tears: the English Funeral Elegy from Spenser to Milton. Oxford: Clarendon, 1990.

Llewellyn, Nigel. Funeral Monuments in Post-Reformation England. Cambridge: Cambridge UP, 2000.

Loades, David. 'Rites of Passage and the Prayer Books of 1549 and 1552.' Prophecy and Eschatology. Ed. M. Wilks. Studies in Church History Subsidia, 10.

McDannell, C. and Lang, B. Heaven: a History. London: Yale UP, 2001.

Marshall, Peter and Alexandra Walsham (Eds). Angels in the Early Modern World.

Cambridge: Cambridge UP, 2006.

Phillippy, Patricia. 'The Mat[t]er of Death: The Defence of Eve and the Female Ars

Moriendi.' Debating Gender in Early Modern England 1500-1700. Ed. C. Malcolmson and

M. Suzuki. Basingstoke: Palgrave Macmillan, 2002. 141-160.

Schmitt, J-C. Ghosts in the Middle Ages: The Living and the Dead in Medieval Society.

London: University of Chicago Press, 1998.

Sherlock, Peter. Monuments and Memory in Early Modern England. Aldershot: Ashgate, 2008.

Shortslef, Emily. 'Acting as an Epitaph: Performing Commemoration in the Shakespeare History Play.' Critical Survey 22 (2010): 11-24.

Stannard, D.E. The Puritan Way of Death: a Study in Religion, Culture and Social Change. New York: Oxford UP, 1977.

Swanson, R.N. (ed.). Catholic England: Faith, Religion and Observance before the

Reformation. Manchester: Manchester UP, 1993.

Targoff, Ramie. Posthumous Love: Eros and the Afterlife in Renaissance England. Chicago: University of Chicago Press, 2014.

Tarlow, Sarah. Ritual, Belief and the Dead in Early Modern Britain and Ireland. Cambridge: Cambridge UP, 2013.

Thomas, Keith. Religion and the Decline of Magic: Studies in Popular Beliefs in Sixteenth and Seventeenth-Century England. London: Penguin, 1991.

West, William N. 'Less Well-Wrought Urns: Henry Vaughan and the Decay of the Poetic Monument.' ELH 75 (2008): 197-217.

Williams, Claire Bryony. 'Manuscript, Monument, Memory: the Circulation of Epitaphs in the $17^{\text {th }}$ Century.' Literature Compass 11(2014): 573-582.

Wiseman, Susan. 'No 'Publick funerall'? Lucy Hutchinson's Elegy, Epitaph, Monument.' Seventeenth Century 30.2 (2015): 207-228. 
Wynne-Davies, Marion. "With such a Wife 'tis heaven on earth to dwell": Memorialising Early Modern Englishwomen.' Journal of the Northern Renaissance 2 (2010).

$<$ http://www.northernrenaissance.org/with-such-a-wife-tis-heaven-on-earth-to-dwellmemorialising-early-modern-englishwomen/>. 